\title{
A new data set of soil mineralogy for dust-cycle modeling
}

\author{
E. Journet $^{1,2}$, Y. Balkanski ${ }^{3}$, and S. P. Harrison ${ }^{1,4,5}$ \\ ${ }^{1}$ School of Geographical Sciences, University of Bristol, Bristol, BS8 1SS, UK \\ ${ }^{2}$ LISA, CNRS - UMR7583, Université Paris-Est Créteil, Université Paris Diderot, Créteil, France \\ ${ }^{3}$ LSCE, CNRS - UMR8212, CEA, Université de Versailles Saint-Quentin, Gif sur Yvette, France \\ ${ }^{4}$ Department of Biological Sciences, Macquarie University, North Ryde, NSW 2109, Australia \\ ${ }^{5}$ Geography \& Environmental Sciences, School of Human and Environmental Sciences, Reading University, \\ Whiteknights, Reading, UK
}

Correspondence to: E. Journet (emily.journet@lisa.u-pec.fr)

Received: 7 June 2013 - Published in Atmos. Chem. Phys. Discuss.: 11 September 2013

Revised: 7 February 2014 - Accepted: 5 March 2014 - Published: 16 April 2014

\begin{abstract}
The mineralogy of airborne dust affects the impact of dust particles on direct and indirect radiative forcing, on atmospheric chemistry and on biogeochemical cycling. It is determined partly by the mineralogy of the dust-source regions and partly by size-dependent fractionation during erosion and transport. Here we present a data set that characterizes the clay and silt-sized fractions of global soil units in terms of the abundance of 12 minerals that are important for dust-climate interactions: quartz, feldspars, illite, smectite, kaolinite, chlorite, vermiculite, mica, calcite, gypsum, hematite and goethite. The basic mineralogical information is derived from the literature, and is then expanded following explicit rules, in order to characterize as many soil units as possible. We present three alternative realizations of the mineralogical maps, taking the uncertainties in the mineralogical data into account. We examine the implications of the new database for calculations of the single scattering albedo of airborne dust and thus for dust radiative forcing.
\end{abstract}

\section{Introduction}

Dust particles, emitted in large quantities by aeolian erosion of arid and semi-arid soils, play an important role on Earth's climate system. During atmospheric transport, they affect Earth's radiative budget directly by absorbing or scattering the solar or infrared radiation (Sokolik and Toon, 1996) or indirectly by acting as cloud condensation nuclei $(\mathrm{CCN})$ or ice nuclei (IN) (Rosenfeld et al., 2001; DeMott et al., 2003; Creamean et al., 2013). Dust also plays a role in atmospheric chemistry (Cwiertny et al., 2008b). Mineral dust deposition to the ocean affects marine biochemistry (Jickells et al., 2005) by increasing the supply of micronutrient iron with implications for the $\mathrm{CO}_{2}$ budget (Martin et al., 1991). Mineral dust may also fertilize terrestrial ecosystems (Okin et al., 2004), particularly in areas such as the Amazon Basin (Swap et al., 1992).

Dust particles are a complex assemblage of various minerals with physicochemical properties that vary widely from one mineral to another. All of the interactions between mineral dust and climate are influenced by the physicochemical properties of the dust particles. Different minerals have different optical properties and thus an accurate specification of mineralogy is necessary to calculate the direct radiative effect of mineral dust. Sokolik and Toon (1996), were the first to suggest incorporating the mineralogical composition of dust particles into models and subsequent work has shown the importance of accounting for mineralogy in estimating the direct radiative effect (Claquin et al., 1999; Sokolik and Toon, 1999; Balkanski et al., 2007; Hansell et al., 2008). Mineralogy also affects the hygroscopic properties of atmospheric particles and thus the indirect radiative forcing by dust. Feldspar minerals, which are a relatively minor component of mineral dust, are highly effective in ice nucleation (e.g., Atkinson et al., 2013). CCN are generally soluble materials and mineral dust aerosols are generally assumed to be nonhygroscopic. However, the conversion of insoluble salts to more soluble compounds through heterogeneous and multiphase reactions, which are highly dependent on the mineralogy of the particles (Kelly et al., 2007), is thought to increase 
the CCN activity of dust (e.g., Levin et al., 1996). Similarly, the reactivity of dust to gases is also dependent on mineralogy (Usher et al., 2003: Krueger et al., 2004). Mineralogy, and in particular the amount and solubility of iron, is key to the impact of dust on marine biogeochemistry (see e.g., Journet et al., 2008; Cwiertny et al., 2008a; Schroth et al., 2009). Iron solubility is highly dependent on its mineralogical form: iron in the structure of clay minerals such as illite or smectite is almost 100 times more soluble than iron oxide minerals such as hematite or goethite (Journet et al., 2008).

The mineralogy of airborne dust is linked to the mineralogy of the erodible fraction of the soil source, although modified by size fractionation during erosion, suspension and transport. Information on the size-resolved mineralogical composition of potential dust sources would significantly improve our ability to predict the mineralogical composition of dust at a global scale. Previous attempts to characterize source-area mineralogy (e.g., Claquin et al., 1999; Nickovic et al., 2012) have focused on soil mineralogy in arid and semi-arid areas. Given that dust-source regions are likely to change in the future (e.g., Mahowald and Luo, 2003; Tegen et al., 2004; Woodward et al., 2005), as indeed they have in the past (e.g., Mahowald et al., 1999; Werner et al., 2002; Takemura et al., 2009), mineralogical information has to be available globally (i.e., not simply for modern-day source regions). Here, we present a new database, created using a similar approach to Claquin et al. (1999) and Nickovic et al. (2012), which describes the size-resolved mineralogical composition of the erodible fraction of soils for most regions of the globe. We then examine some of the consequences of using this database to specify the properties of airborne dust.

\section{Construction of the database}

The database contains information of the relative abundance of 12 minerals: quartz, feldspars, illite, smectite, kaolinite, chlorite, vermiculite, mica, calcite, gypsum, hematite and goethite. This is an expanded set of minerals compared to the Claquin et al. (1999) and Nickovic et al. (2012) compilations. We first estimate the distribution of these minerals in different size classes, including characterizing the iron species in the clay fraction. We then determine the average size-resolved mineralogical composition for each soil unit of the FAO (The Food and Agriculture Organization of the United Nations) soil classification (FAO, 1990a).

\subsection{Distribution of minerals by size class}

The mineralogical composition of airborne dust depends on both the mineralogy of the soil source and size fractionation during emission and transport. Only the smallest soil particles are light enough to stay in suspension in the atmosphere and to be transported long distances. To be able to account for these fractionation effects, we specify the mineralogical
Table 1. Distribution of the selected minerals in the clay and silt fraction of soils.

\begin{tabular}{lll}
\hline Minerals & Clay fraction & Silt fraction \\
\hline Illite & Dominant $(100 \%)$ & Negligible (0\%) \\
Kaolinite & Dominant $(100 \%)$ & Negligible (0\%) \\
Smectite & Dominant $(100 \%)$ & Negligible $(0 \%)$ \\
Vermiculite & Dominant $(100 \%)$ & Negligible (0\%) \\
Chlorite & Present & Present \\
Mica & Negligible (0\%) & Dominant (100\%) \\
Quartz & Minority & Majority \\
Feldspar & Minority & Majority \\
Gypsum & Negligible (0\%) & Dominant (100\%) \\
Calcite & Present & Present \\
Hematite & Dominant $(100 \%)$ & Negligible $(0 \%)$ \\
Goethite & Present $(70 \%)$ & Present $(30 \%)$ \\
\hline
\end{tabular}

composition of the finer textural classes of soils: the silt and the clay fraction. There are insufficient measurements to assign an explicit size range for each mineral, so we determine an average mineralogy for each size class.

Primary minerals (quartz, feldspars and mica) are mostly found in the silt-sized fraction and secondary minerals (clay minerals, soluble minerals and iron oxide minerals) in the clay-sized fraction. We adopted an allocation, summarized in Table 1, as follows.

1. Clay minerals (illite, smectite, kaolinite and vermiculite) are important chemical weathering products, are small and mostly belong to the clay-size fraction (Pedro, 1984).

2. The clay mineral, chlorite is an exception since it occurs both in the clay-size class and throughout the silt range (Griffin et al., 1968), depending on whether it is formed by hydrothermal alteration or inherited from bedrock.

3. Mica is a primarily a phyllosilicate mineral and consequently is silt-sized or coarser (Mitchell and Soga, 2005).

4. Quartz and Feldspars are present in all size fractions of soils. They are present in only minor amounts in the clay fraction, but are abundant in the silt fraction (Rahn, 1976; Chatenet et al., 1996).

5. Gypsum is most often found in the coarser fraction of soils (FAO, 1990b) and is therefore only allocated to the silt fraction.

6. Calcite seems to be present in all size fractions. Abtahi (1980) has shown that calcite occurs mostly in the large-size fractions of arid soils, but can also be found in significant quantity in the fine fractions. Therefore, we assign calcite to both the clay and silt fractions. 
Table 2. Average iron content in selected minerals.

\begin{tabular}{llc}
\hline Mineral & References & $\begin{array}{l}\text { Mean Fe } \\
(\text { wt } \%)\end{array}$ \\
\hline Illite & $\begin{array}{l}\text { Journet et al. (2008), Seabaugh et al. (2006), Taylor et al. (2000), Gold et al. (1983), Robert (1973), Carroll } \\
\text { and Starkey (1971), Deer et al. (1962) }\end{array}$ & 4.3\% \\
Smectite & $\begin{array}{l}\text { Journet et al. (2008), Ramesh et al. (2007), Bayrak (2006), Garcia-Rodriguez et al. (1995), Yilmaz (1981), } \\
\text { Osthaus (1956) }\end{array}$ & 2.6\% \\
Kaolinite & Journet et al. (2008), Temuujin et al. (2001) & $0.23 \%$ \\
Chlorite & Cathelineau and Nieva (1985), Kramm (1973) & $12.5 \%$ \\
Vermiculite & Andronova (2007), Seo et al. (2005) & $6.7 \%$ \\
Feldspars & Journet at al. (2008) & $0.34 \%$ \\
\hline
\end{tabular}

7. Iron oxide minerals are generally formed through the alteration of the most common rocks. Their mineralogy and crystallinity reflect the alteration environment and are strongly linked to climatic conditions (Cornell and Schwertzmann, 2003). Iron oxide minerals occur as very small individual particles (50-100 ̊) (Greenland et al., 1968), often in combination with particles of kaolinite or as aggregates (e.g., Schwertmann and Kampf, 1985). Hematite and goethite are the most common iron oxide minerals found in soil. Kandler et al. (2009) showed that $66 \%$ of the total iron oxide minerals are in the clay fraction and $33 \%$ in the silt. There is no size-resolved iron species data available and the limited evidence for the size distribution of hematite and goethite is conflicting. Gangas et al. (1973), for example, claim that hematite and goethite are concentrated in the clay fraction, while Lafon et al. (2004), found an even distribution between the clay- and silt-sized fractions of three arid soils. Coudé-Gaussen (personal communication, 1999) suggests that goethite particles are common on large quartz grains of size $>40 \mu \mathrm{m}$. We assume that only goethite is found in both size fractions, and hematite is confined to the clay fraction.

\subsection{Iron content of the clay-size fraction}

The mineralogical speciation of iron is distinguished in the database because iron from clay minerals is more soluble than iron from hematite or goethite (Journet et al., 2008). The total elemental iron content in the clay fraction is estimated from the iron content for each mineral. This method does not account for variations that reflect the conditions in which the minerals were formed. Hematite and goethite are the most iron-rich minerals. According to their stoichiometry, hematite $\left(\mathrm{Fe}_{2} \mathrm{O}_{3}\right)$ contains $69.9 \%$ iron and goethite (FeOOH) $62.8 \%$. Clay minerals and feldspars also contain a small proportion of iron trapped in their crystal lattice. The estimated iron content of the different minerals present in the clay fraction, collected from the literature, is given in Table 2.

\subsection{Associating mineralogy with soil unit}

Mineralogy is not a diagnostic criterion used in soil profile descriptions or a property used in soil classification. Following Claquin et al. (1999), we hypothesize that the mineralogy of the surface depends on the size distribution, the chemistry and the color of the soil, in order to infer an average mineralogical composition for each soil unit. We use the Harmonized World Soil Database (HWSD; FAO/IIASA/ISRIC/ISSCAS/JRC, 2009), a 30 arcsecond raster database, to determine the geographic distribution of soil units. The HWSD uses the FAOUNESCO soil classification system, which is based on soilprofile descriptions and the presence of diagnostic horizon(s). The FAO soil classification has undergone several revisions since it was first used for The Legend of the Soil Map of the World (FAO-UNESCO, 1974). The number of major soil groups has been increased, from 26 major soil groups in the 1974 version, to 28 in the 1990 version (FAO, 1990a). Each major soil group is divided into second-order soil units. The number of soil units also expanded between the 1974 and 1990 versions. For example, the Arenosols were subdivided into 4 soil units in the 1974 version (albic, cambic, ferralic and luvic) but 7 units in the 1990 version (albic, calcaric, cambic, ferralic, gleyic, haplic and luvic). The HWSD combines both versions of the classification, giving a total of 211 individual soil units. The HWSD incorporates a number of regional and national updates of the soil information. Although information on soil properties (e.g.,textural class, calcium carbonate and gypsum content) is available for each soil unit, individual units are grouped together into soil associations, designated by the dominant soil unit, for mapping purposes.

\subsection{Database of topsoil mineralogy}

We conducted an extensive literature review to compile the available descriptive data on soil mineralogy. To select representative measurements for each soil, we used the following criteria. 
1. The mineralogical analyses were made on sizeresolved fractions: the clay fraction $(<2 \mu \mathrm{m})$ and/or on the silt fraction (between 2 and $63 \mu \mathrm{m}$ ).

2. The mineralogical analyses were made on the topsoil (surface horizon) because subsurface layers are not subject to aeolian deflation.

3. The information is compiled for soil samples which can be identified according to the FAO soil classification.

Only data that met all three criteria were retained. The database compiles quantitative information on the mineralogical composition of the clay and/or the silt fractions of soil samples and associated metadata including the source of the mineralogical information. The geographic coordinates of the original data are collected; either obtained directly from the source publication or inferred from the description of the general location of the soil profile. We also compiled the soil-sample texture (relative proportion of clay, silt and sand fractions); when this information was lacking, we used the mean texture of the corresponding FAO soil units given in the HWSD. The standard method of determining soil texture involves wet sieving, and thus results in the loss of soluble minerals such as calcite or gypsum. When size-resolved estimates were not available, we therefore included the total calcite and gypsum content of the bulk soil $(<2 \mathrm{~mm})$. Iron oxide minerals (hematite and goethite) occur in very small quantities in most soils and their abundance is rarely quantified. We used the fact that the presence of iron oxide minerals in the soil results in a distinctive red or yellow coloration (Torrent et al., 1983), together with a compilation of soil sample color (according the Munsell Soil Color Charts; Munsell Color Company, 1975). The hematite and goethite content can be then inferred from the soil color according the relationships established by Torrent et al. (1983) and by Fontes and Carvalho (2005).

The final database contains data from 700 soil descriptions from more than 150 publications. Most of the records (ca. 600) document the mineralogy of the clay fraction; there are far fewer records for the silt fraction. The spatial distribution of the data is shown in Fig. 1. There is little data from Russia, Alaska, Canada and Greenland, and records are sparse across central Asia as much of the information from this region is in Chinese language publications. The distribution of records from other regions is inhomogeneous: the North American records are mostly from the western part of the continent, the South American records from Argentina and Brazil, while there is little or no data from West and central Africa or from central Australia. Nevertheless, the database represents a substantial improvement on the Claquin et al. (1999) compilation (Fig. 1) and samples 55\% of the FAO soil units.

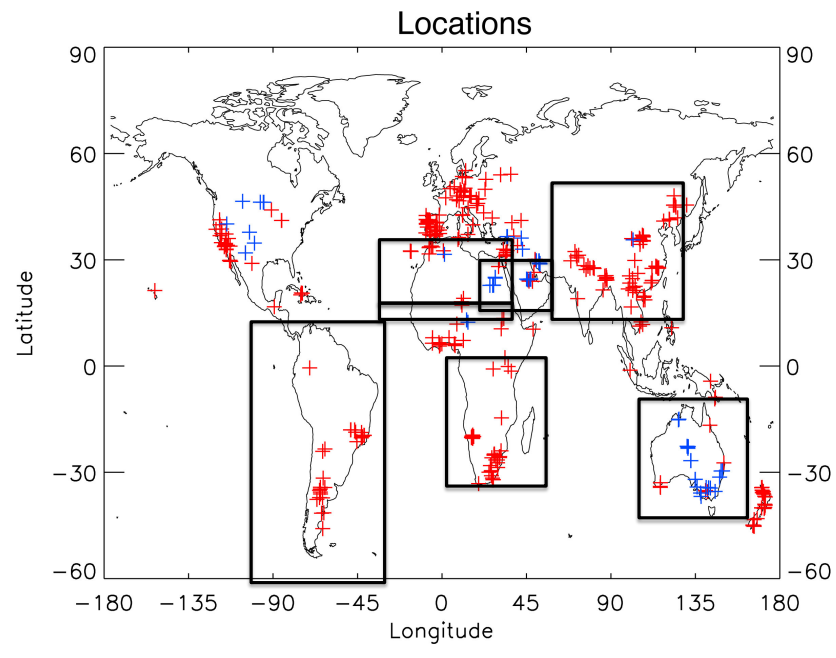

Fig. 1. Location of the data collected for this work (in red) and from Claquin et al. (1999) (in blue). The rectangles delimit regions studied in Fig. 8.

\subsection{Expansion of the database and production of the mean mineralogical tables}

Despite the extensive literature compilation, the database is deficient in information about the calcite, hematite and goethite content of the clay fraction. Information about silt mineralogy is very sparse: quantitative information on the amount of quartz, feldspars, mica and is available for only 25 soil units (see Table S2 in the Supplement), and the amounts of calcite, gypsum and goethite are lacking in many cases. To overcome these problems, we have used a number of empirical approaches (described below) to fill critical gaps in creating the final, mean mineralogical tables used to produce the mineralogical maps.

The HWSD give, for each soil unit of the FAO classification, the total amount of calcite and gypsum. Analysis of the available data shows that the amount of $\mathrm{CaCO}_{3}$ in the clay and silt fractions is linearly related to the clay/silt content of the soil (Fig. 2). Thus, we estimate the amount of calcite in the clay and the silt fraction of each soil unit from the total $\mathrm{CaCO}_{3}$ and the amount of clay/silt in that soil as Claquin et al. (1999) had already done and we assume that the total amount of gypsum is divided equally between the silt and the sand fractions. Using these estimates, we have assigned to each of the 211 soil units the calcite content of the clay fraction and the calcite and gypsum content of the silt fraction.

To access the hematite and goethite content, we applied the empirical relationships established by Torrent et al. (1983) and Fontes and Carvalho (2005) between soil color and hematite and/or goethite content. Soil color is determined through visual comparison with the Munsell Soil Color Charts (Munsell Color Company, 1975). Color indices were developed on the basis of the Munsell notation: (i) the redness rating (RR) (Torrent et al., 1983) as a numerical index 

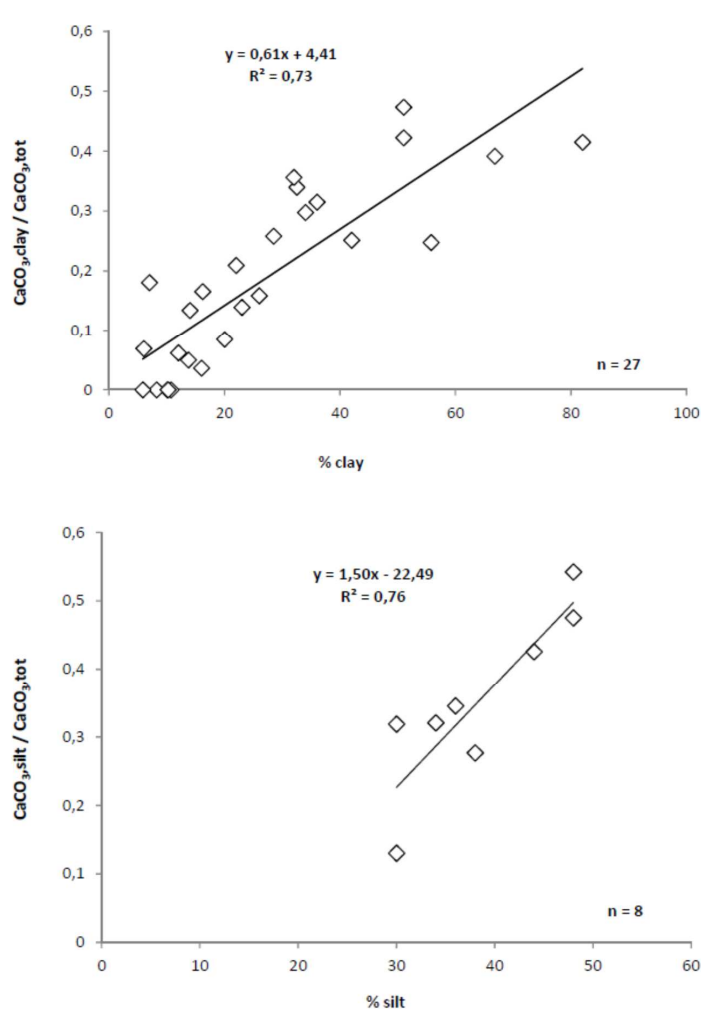

Fig. 2. Empirical relationships between (a) the calcite content of the clay fraction and the ratio of the calcite in the clay fraction to the one in soil and (b) the calcite content in the silt fraction and the ratio of the calcite in the silt fraction to the one in soil.

that could measure quantitatively the relationship between the redness and the hematite content in soil, (ii) the redness factor (RF) (Fontes and Carvalho, 2005) as a numerical index that allows estimating the hematite to goethite ratio in soil. The inferred hematite content is entirely allocated to the clay fraction of the soil. The inferred goethite content is allocated to both the clay and the silt fractions. Following size-resolved mineralogical data provided by Kandler et al. (2009) for mineral dust particles sampled close to an African source area, $67 \%$ of the goethite was assigned to the clay fraction and $33 \%$ to the silt fraction. Thanks to these estimates, goethite and hematite content is now available in the clay fraction for 92 soils units and goethite in the silt fraction for 63 of the soils units.

As we have very little information for the silt fraction, we decided to assign the same quartz and feldspars content for all soil units within a major soil group, on the assumption that the content of these minerals in soils is determined by the mineralogy of the original bedrock and the classification of major soil groups is strongly related to the nature of the bedrock. The mica and chlorite contents of soils, however, is determined by soil-forming processes not bedrock mineralogy. Where quantitative information on mica and chlorite content is missing, we assign an average value based on the average of all the silt-fraction records.

Finally, the use of such estimates allows us to attribute a mean mineralogical composition of the clay fraction for 92 of the 211 soil units. For 28 of the remaining units, for which soil color information was lacking, we assumed that the hematite and/or goethite content was that of the major soil class to which the units belong. Data on the average clay mineralogical composition of the 120 soil units are presented in Table S1 in the Supplement. Nevertheless, there are still 91 soil units for which there is no information about the mineralogical composition of the clay fraction in the database but for calcite.

For the silt fraction, using these approximations, we are able to specify the calcite, gypsum, mica and chlorite content for all the 211 units, the goethite content for 181 soil units and the quartz and feldspar contents for 113 soil units.

\subsection{Creation of the mineralogical maps}

The mean mineralogical tables provide mass percentages for ten minerals (illite, smectite, kaolinite, chlorite, vermiculite, feldspars, quartz, calcite, hematite, goethite) and the total elemental iron content in the clay-sized fraction and mass percentages of six minerals (feldspars, quartz, mica, chlorite, calcite and goethite) in the silt-sized fraction for individual FAO soil units. These values are assigned to all the geographical locations with the soil unit corresponding to the HWSD database. The HWSD grid is then aggregated onto a regular grid with a resolution of $0.5^{\circ} \times 0.5^{\circ}$. The resultant mineralogical map only shows information for soil units for which there was primary or derived mineralogical data. When mineralogical information is available for less than $50 \%$ of the grid cell area, these cells are not mapped (white areas in Fig. 3). Two further maps were created for the clay mineralogy of soils. In the first map (CASE 1), we assign a mineralogical composition to the 120 soil units for which we have no information in the database, based on the mineralogical composition of the soil units whose profile characteristics are the closest. In the second map (CASE 2) we assign the average mineralogical composition of the major soil group to which the missing units belong to. The CASE 1 and CASE 2 maps have continuous coverage.

Even for the baseline case (CASE 0), there is good coverage of the tropics and midlatitude regions, particularly midlatitude regions of the Southern Hemisphere (Fig. 3). Most of the modern-day arid and semi-arid source areas are well covered: there is mineralogical data for more than $90 \%$ of the Sahara/Sahel and Middle East dust sources, and more than $80 \%$ of the South African and South American dust sources. The coverage of Chinese, Australian and North American dust sources is poor, in large part because of the lack of mineralogical data for the most widespread soil units (luvic Kastanozem, luvic Yermosol) in these regions. The lack of information about Australian dust sources is due to the fact that 


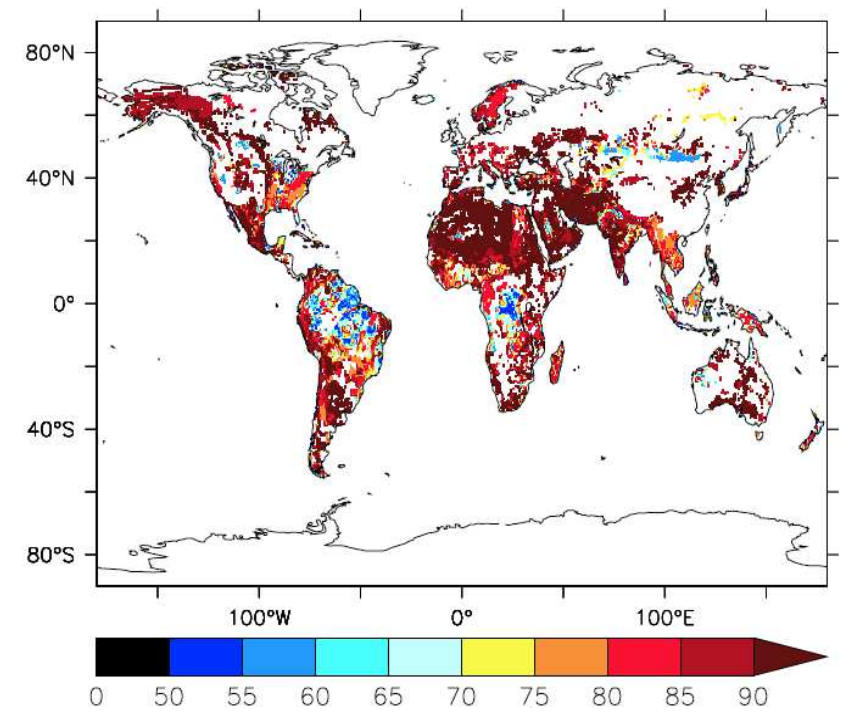

Fig. 3. Percent of soil area where clay mineralogy exists in the database.

most of the soil data comes from coastal regions (Fig. 1). The data set provides reasonable coverage of tropical and midlatitude regions that are not sources today. Because data on gelic soils (i.e., with permafrost) were not included in the database, there is poor coverage for the high latitudes of the Northern Hemisphere (NH) and the Tibetan Plateau.

\section{The mineralogical maps}

\subsection{Minerals in the clay fraction: the example of illite}

Illite occurs in almost all soil units and is therefore represented across all regions of the globe (Fig. 4). The amount is highly variable, ranging from 0 to $94 \%$ with a mean value at $20.5 \%$. The highest amounts are found in the NH high and midlatitudes, under cool and temperate climates. This is consistent with the controls on the clay mineral formation: where water is scarce and temperature is low, physical alteration predominates and favors minerals similar to those of the parent rock, predominantly illite. The lowest amounts of illite are found in the wet equatorial zone where soil hydrolysis limits its occurrence. Previous studies (Caquineau et al., 2002; Claquin et al., 1999) have suggested that there was a latitudinal gradient in the amount of illite present in North Africa, but this is not so obvious in our dataset. The highest amounts of illite in this region occur east and south of the Sahara, associated with haplic and cambic Arenosols.

\subsection{Mineralogy of the silt fraction: the example of mica}

Mica and gypsum only occur in the silt fraction. The gypsum content of soils is always $<2 \%$ and relatively homogeneous; the mica content is more variable. Although mica contents of

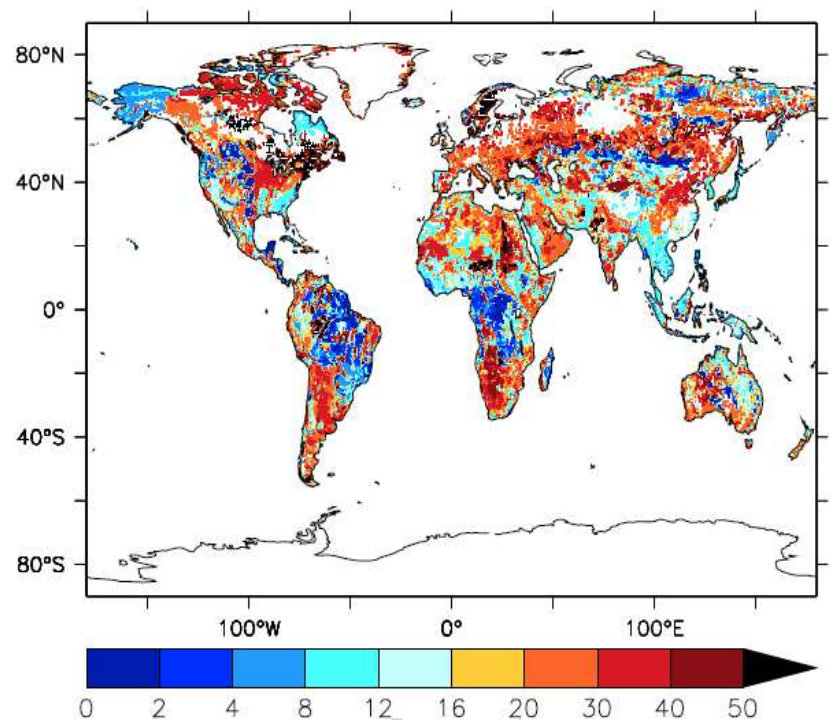

Fig. 4. Illite content in the clay fraction of soils (CASE 1).

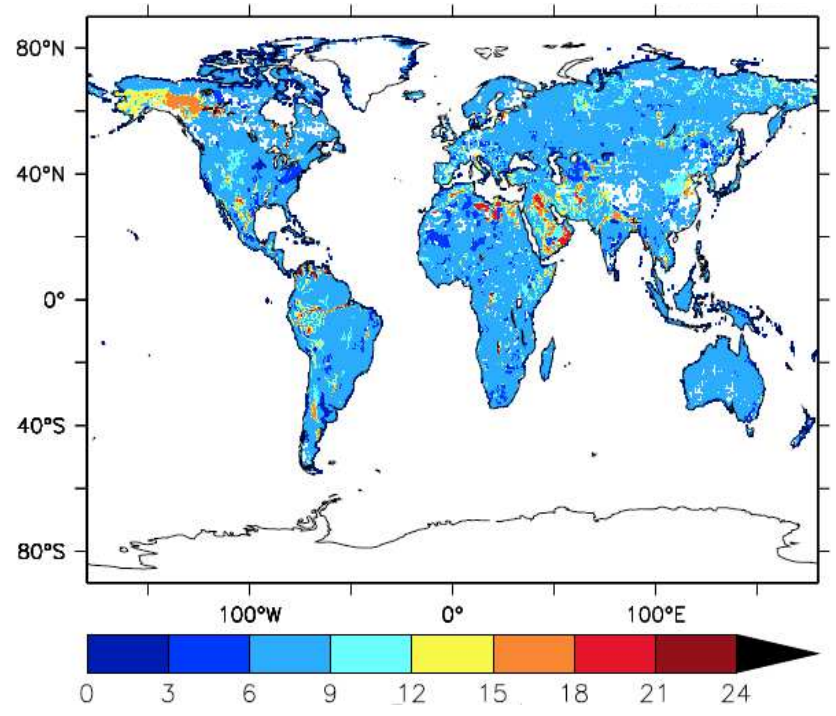

Fig. 5. Mica content in the silt fraction of soils.

up to $25 \%$ are obtained, most areas have between 6 and $9 \%$ mica (Fig. 5). This homogeneity may reflect the assignment of average values to soil units lacking specific data. However, mica-rich soils occur locally in Alaska, along the Mediterranean coast of North Africa, in the Middle East, in northern India and in eastern China.

\subsection{Minerals occurring in both silt and clay fractions: the example of calcite}

Calcite occurs in both the silt and clay fractions of soils. The amount of calcite in the silt fraction is generally low, rarely exceeding $5 \%$ in the Southern Hemisphere (SH) and only exceeding $12 \%$ in the $\mathrm{NH}$ in the hot deserts of the northern 

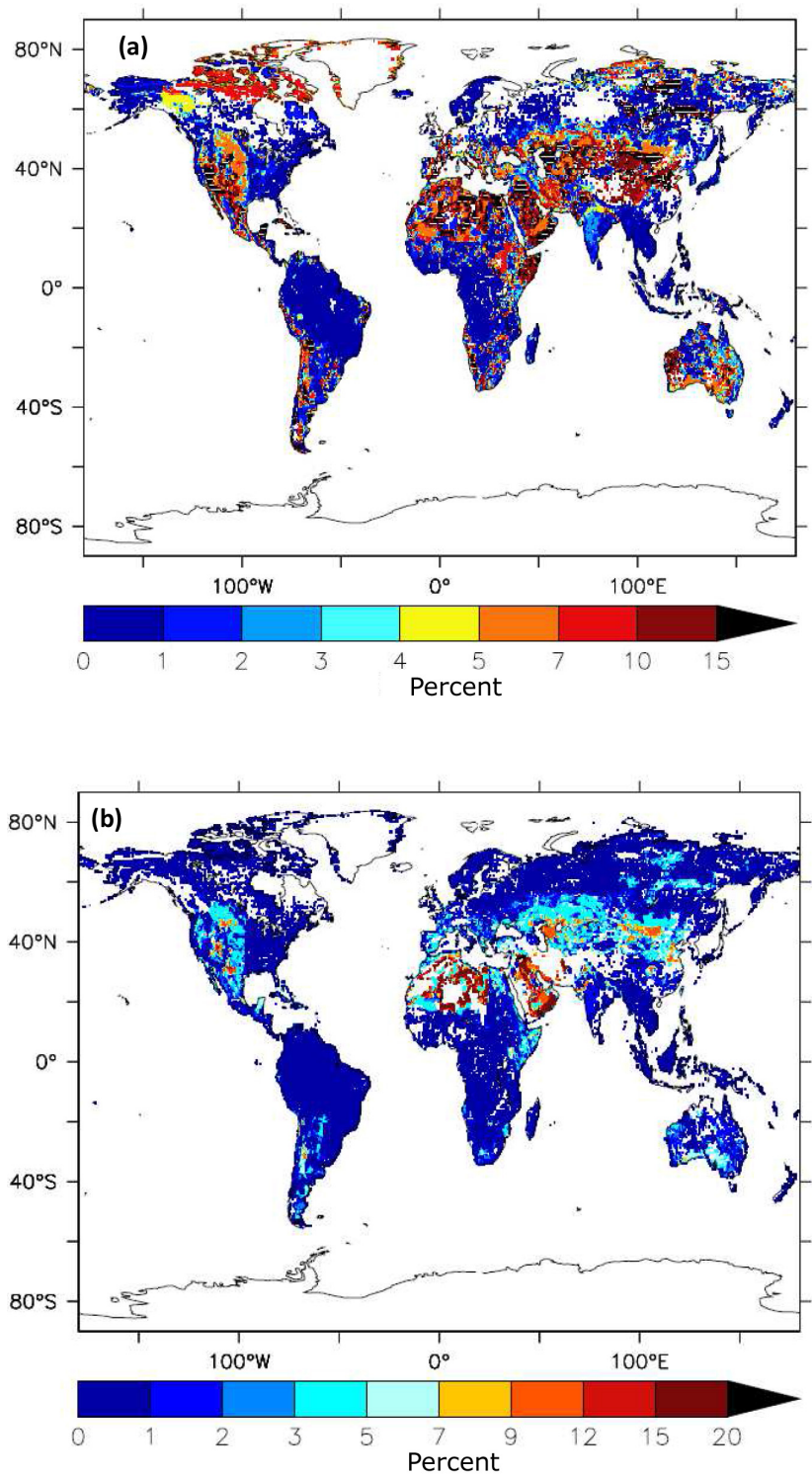

Fig. 6. Calcite content (a) in the clay fraction of soils (CASE 1) and (b) in the silt fraction of soils.

intertropical zone (Sahara and Middle East) where it reaches $25 \%$ (Fig. 6). A similar pattern is seen in the clay fraction, but the amounts are larger (up to $40 \%$ ). The calcite content in the clay fraction is closely related to rainfall: calcite content is low in regions where the annual rainfall is $>400 \mathrm{~mm}(<1 \%)$, varies between 5 and $15 \%$ in semi-arid regions (200 and $400 \mathrm{~mm}$ ) and only exceeds $15 \%$ in arid areas where annual rainfall is $<200 \mathrm{~mm}$.

\subsection{Distribution of total elemental iron and iron oxide minerals}

The total elemental iron content of the clay fraction ranges between 0 and $15 \%$ (Fig. 7a). The total elemental iron content reflects not only the presence of hematite and goethite but also the presence of clay minerals such as illite or smectite. These minerals contain substantial quantities of iron (around $3 \%$ according Journet et al., 2008). Due to their high abundance in dust, estimates of total iron in dust have to account for the iron associated with both illite and smectite. The hematite content in the clay fraction is usually $<1.5 \%$ (Fig. 7b) but reaches $5 \%$ in some regions, including the longitudinal band from Montana to Texas in the US, a latitudinal band across southern Russia, and arid regions of northern Africa, while soils in southern Brazil/northern Argentina have hematite contents $>5 \%$. Goethite occurs in both the clay- and silt-sized fractions. The amount of goethite in the clay fraction is generally higher than the amount of hematite, and more variable (from 0 to $15 \%$ ). The highest amounts of goethite are found in moist soils in the equatorial zone and over part of the eastern US. The amount of goethite in the silt fraction is more homogeneous and represents $<2 \%$ of the mass except in the equatorial zone where it can reach $>5 \%$, as in soils in Brazil. Goethite is generally more abundant in humid tropical environments while hematite becomes more abundant in the seasonally dry tropics.

\subsection{Mineralogical composition over modern dust-source regions}

The largest sources of dust emissions to the atmosphere are located in the NH "dust belt" that extends from northern Africa to the Middle East, and from central and southern Asia to China. Dust emissions also occur from arid areas in South America, South Africa and central Australia. The dust from a particular source generally influences a specific region (Griffin et al., 2002). Dust from northern Africa, for example, is transported over the North Atlantic (Delany et al., 1967) and the Mediterranean Basin (Ganor and Mamane, 1982) and into Europe and the Americas, while dust from Asia is transported over the North Pacific to North America (Duce et al., 1980). We defined seven dust-source regions (Arabia: $13-23^{\circ} \mathrm{N}, 25-65^{\circ} \mathrm{E}$; Asia: $10-50^{\circ} \mathrm{N}, 65-130^{\circ} \mathrm{E}$; Australia: $110-160^{\circ}$ E, $45-10^{\circ} \mathrm{S}$; South Africa: $35-0^{\circ} \mathrm{S}, 2-$ $52^{\circ} \mathrm{E}$; South America: $62^{\circ} \mathrm{S}-10^{\circ} \mathrm{N}, 100-30^{\circ} \mathrm{W}$; Sahara: $16-$ $36^{\circ} \mathrm{N}, 25^{\circ} \mathrm{W}-42^{\circ} \mathrm{E}$; and Sahel: $10-16^{\circ} \mathrm{N}, 25^{\circ} \mathrm{W}-42^{\circ} \mathrm{E}$ ) and calculated an average mineralogical composition for each region (Fig. 8) to examine whether the differences in the mineralogy of airborne dust were large enough to influence regional climate. The average composition was calculated by weighting the mineralogical composition of each soil unit within the region by the percentage of surface it covers.

Kaolinite is the dominant mineral in all the source regions, but the abundance varies from 24 (Arabia) to $36 \%$ (South Africa). The next most abundant minerals are illite and smectite. The total amount of clay minerals (kaolinite, illite, smectite, vermiculite and chlorite) ranges between 56 and $75 \%$. Quartz and feldspars never exceed $6 \%$ of the clay fraction. In contrast, the amount of calcite varies from region to region: 

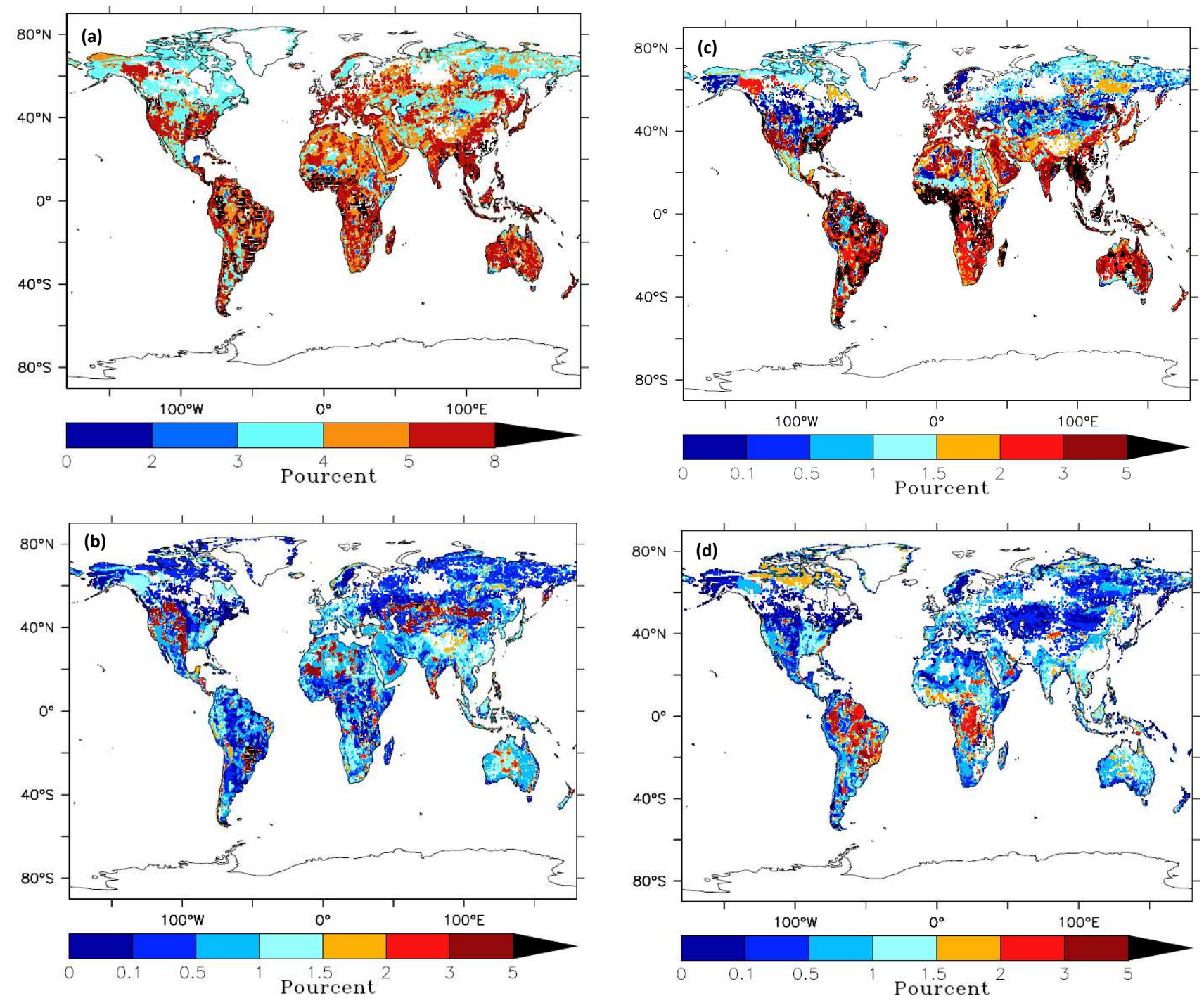

Fig. 7. Iron and iron oxides in soils: (a) iron in the clay fraction (CASE 1), (b) hematite in the clay fraction (CASE 1), (c) goethite in the clay fraction (CASE 1) and (d) goethite in the silt fraction.

the South African, South American and Sahelian sources have $<4 \%$ whereas the Arabian and Saharan sources have values of around $9 \%$. The amount of iron oxide minerals in the clay fraction vary from 3.0 (Arabia) to $4.6 \%$ (South America, South Africa). The total elemental iron content of each source ranges between 4 and $5 \%$ of the clay fraction (Fig. 9). More than half is associated with iron oxide minerals (goethite and hematite), while the rest is Fe associated with the aluminosilicate lattice of clay minerals such as illite and smectite. Vermiculite and chlorite are less abundant in the soil but also contribute to the total elemental iron.

The largest differences between regions are for vermiculite and calcite (relative standard deviations, RSD, ca. 50\%) and to a lesser extent, because of its very low abundance in the clay fraction, feldspars. Regional differences for the other minerals are less marked (RSD ca. 20\%). The amount of illite $(20.1 \pm 2.5 \%)$ and elemental iron $(4.5 \pm 0.4 \%)$ are similar from region to region. The source areas of South Africa and South America have a similar mineralogical composition (high kaolinite, low calcite and smectite, and high iron from goethite), which is nevertheless distinct from the mineralogical composition of the Sahara and Arabia sources (low kaolinite, high calcite, and relatively low iron).

\subsection{Differences between soil and airborne dust mineralogy}

We use a general circulation model with an aerosol scheme (LMDZ-INCA) to transport the minerals as individual tracers. For each mineral, 5 years of simulations were analyzed after a 3-month initialization period used to bring the aerosol distribution to a steady state. These simulations allowed us 

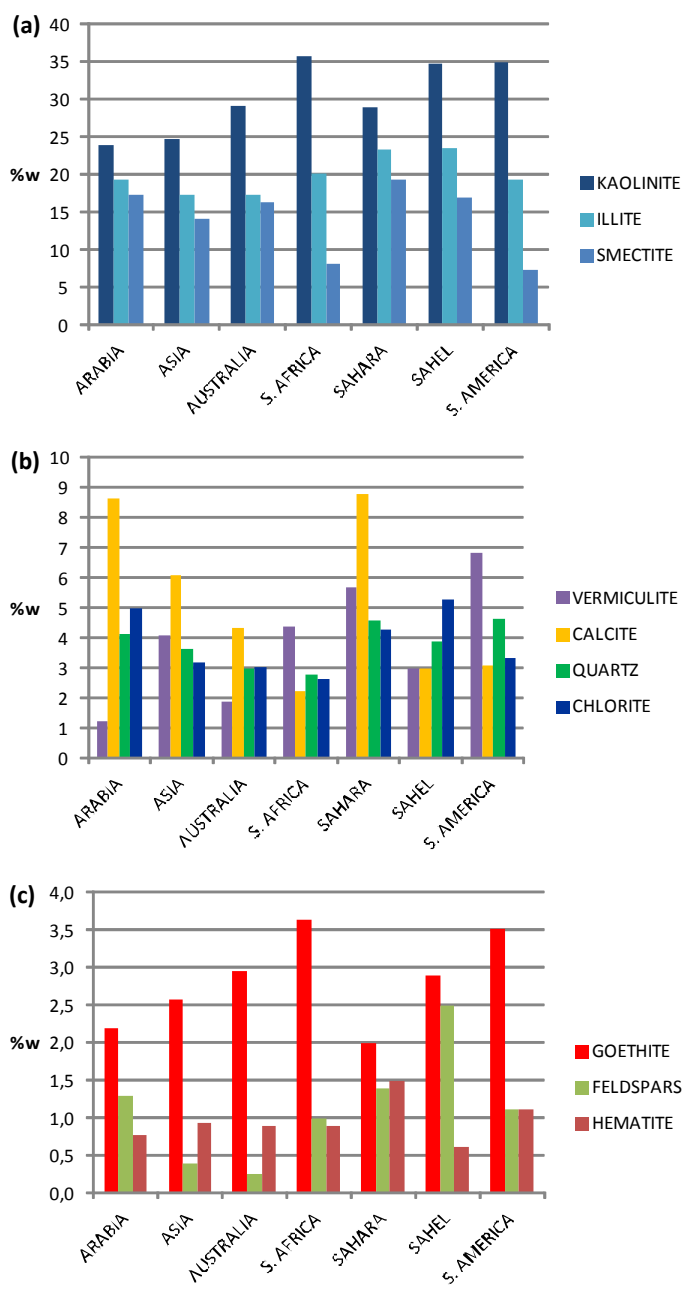

Fig. 8. Average mineralogical composition of the major dust-source regions (clay fraction, CASE 0). Top panel: the three major clay minerals with content higher than $5 \%$; middle panel: calcite and quartz with contents ca. $5 \%$; and bottom panel: minerals which contribute less than $4 \%$ of the mass: iron oxides and feldspars.

to determine the volume fraction of the different minerals relative to the volume of total dust. Each mineral is transported in the atmosphere using a modal scheme to represent the size distribution with a mass median diameter of $2.5 \mu \mathrm{m}$ and a $\sigma$ of 2.0 (Schulz et al., 1998). Figure 10 illustrates the global averaged differences in mineralogy between the clay fractions of soil and airborne dust. The mineralogical composition of airborne dust is broadly similar to that of the clay fraction of the soil. The most abundant minerals in both soil and airborne dust are kaolinite, illite and smectite, which represent $68.6 \%$ (by mass) of the soil and $64.5 \%$ of the airborne dust. Kaolinite is less abundant in airborne dust than soil (23.6 versus $35.3 \%$ ), whereas the amount of illite and smectite is slightly higher in airborne dust. The largest differences between soil and airborne dust are in terms of the abundance of feldspars and of minerals outside the group

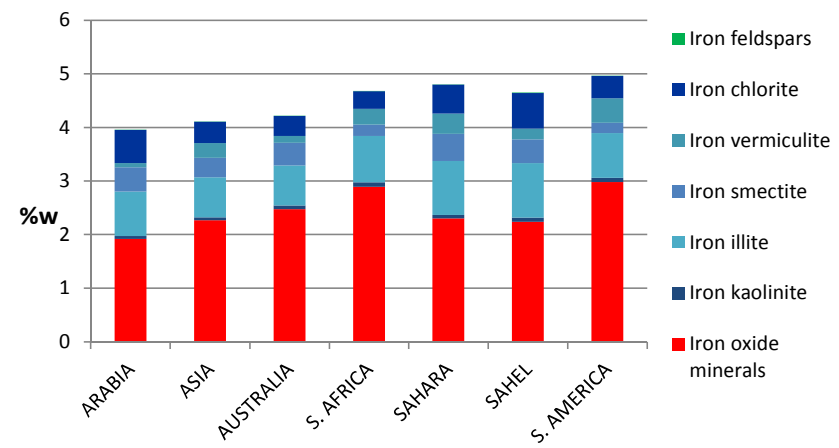

Fig. 9. Average iron content and speciation of the major dust-source regions (clay fraction, CASE 0).

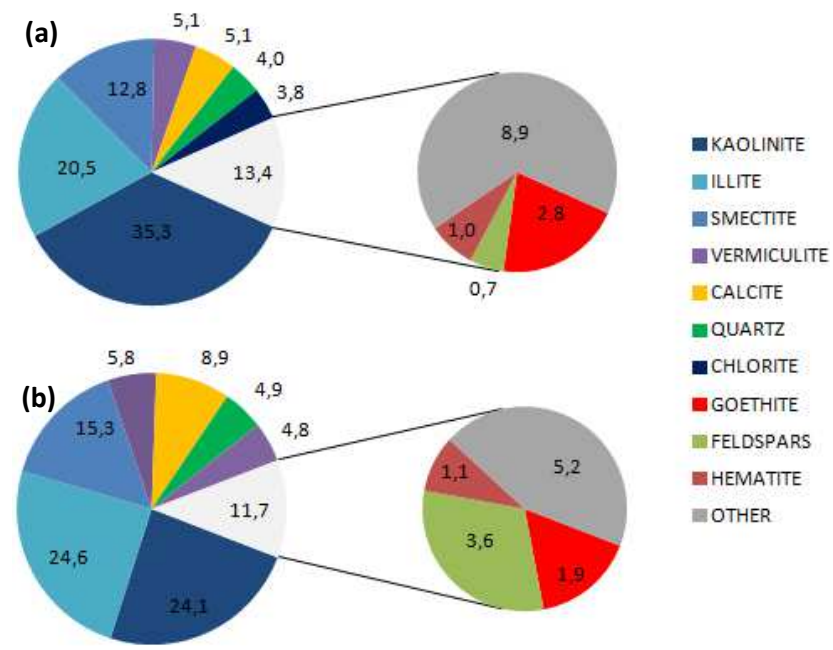

Fig. 10. Global yearly average composition (in mass percentage) of (a) clay fraction of soil and (b) airborne minerals.

considered here (other). Feldspars are not abundant in the soil $(0.7 \%)$ but are a significant component of airborne dust (3.7\%); other minerals form $8.9 \%$ of the soil and only $5.2 \%$ of airborne dust. These differences reflect the fact that the values for the soil are the average composition of all the world's soils whereas the airborne dust is related only to the dust-producing regions.

The distribution of illite in the clay fraction of soils and yearly-averaged airborne dust from our CASE 0, CASE 1 and CASE 2 maps is shown in Fig. 11. Illite comprises between 20 and $30 \%$ of the total mass of airborne dust over most of the Northern Hemisphere in CASE 0 and CASE 1. Emissions from the Lake Chad region and the Taklamakan Desert contribute to the elevated illite content that creates a north-south gradient. In contrast, CASE 2 shows a relatively low illite fraction over the Gobi Desert.

Feely et al. (2009) assume that transported calcite has a mass content of $3 \%$, and use this fraction to limit the heterogeneous uptake of acids such as nitric acid by mineral dust. This is not consistent with our results, where the calcite 
fraction in the three different cases ranges from 7.9 to $8.9 \%$ of the mass of the airborne clay fraction. Airborne calcite exceeds $12 \%$ in the clay fraction over Mauritania, Morocco and the western US (Fig. 12).

\section{Discussion}

\subsection{Comparison with Claquin et al. (1999) and Nickovic et al. (2012) results}

The Claquin et al. (1999) and Nickovic et al. (2012) data sets provides mineralogical information for arid dust-source regions. The only difference between these two existing databases is the extension of the mineralogical table for three new soil units (Yermosols, haplic Yermosols and Xerosols) by Nickovic at al. (2012) in comparison with Claquin et al. (1999). In the present paper, we recreated the whole database. We have extended this approach to cover soils over most of the world (with the exception of cold areas with permafrost), on the assumption that this will be useful for specifying dust mineralogy as dust sources change in response to climate changes. We have been able to capitalize on the much-expanded literature now available to provide mineralogical information of the clay fraction for 120 soil units described in the FAO classification. The number of minerals considered was also increased, compared to Claquin et al. (1999) and Nickovic et al. (2012), by adding information on chlorite, vermiculite, feldspars, goethite and hematite in the clay fraction. Although relatively unimportant by mass individually, together these minerals can be ca. $45 \%$ of the mass in some soil units (e.g., Humic Ferralsols). We have added mica and chlorite in the silt fraction, and attribute the iron oxide in this fraction to goethite (rather than hematite as in Claquin et al., 1999 and Nickovic et al., 2012). We have chosen not to normalize the distribution of individual minerals to $100 \%$ of the mass, in order to avoid artificially inflating the amount of an individual mineral recorded; up to $17 \%$ of the mass remains unidentified for some soils.

A comparison of databases has been established for 20 soil units that are listed Table 3. The average composition of the clay fractions obtained from the database of Nickovic et al. (2012) and from this work for the 20 soil units are shown in Fig. 13. Whatever the database, the major component of the clay fraction are clay minerals (kaolinite, illite and smectite), and the estimates of their cumulative abundance is almost always higher in the work of Nickovic et al. (2012) than in this work even if we add two additional clay minerals (chlorite and vermiculite). This can be partly explained by the fact that Nickovic et al. (2012) normalize the distribution of individual minerals to $100 \%$ of the mass unlike us. In both databases, the range in calcite content is the same, between 0 and $30 \%$ but in average the calcite content is higher in this work compared to the one obtained by Nickovic et al. (2012). We observe significant differences for
Table 3. Soil units used for comparison of databases (see Fig. 13).

\begin{tabular}{lll}
\hline 1 & Arenosols & cambic \\
2 & Arenosols & luvic \\
3 & Fluvisols & calcic \\
4 & Fluvisols & eutric \\
5 & Lithosol & - \\
6 & Regosols & calcaric \\
7 & Regosols & eutric \\
8 & Salt flats & - \\
9 & Sand dunes & - \\
10 & Solonetz & orthic \\
11 & Solontchaks & gleyic \\
12 & Solontchaks & orthic \\
13 & Vertisols & chromic \\
14 & Xerosols & calcic \\
15 & Xerosols & haplic \\
16 & Xerosols & luvic \\
17 & Xerosols & - \\
18 & Yermosols & calcic \\
19 & Yermosols & haplic \\
20 & Yermosols & - \\
\hline
\end{tabular}

calcite especially for Yermosols (3), haplic Yermosols (5), eutric Regosols (9), luvic Xerosols (11) and sand dunes (4) where the difference can exceed $150 \%$. We now discuss the evolution of the database between the two versions. The significant differences on calcite content result largely of the empirical relationship between the calcite content in the clay fraction and the total calcite content and the amount of clay in soil (Fig. 2) which is different between Claquin et al. (1999) and this work. The new relationship established in the present work leads to higher calcite content in the clay fraction for the same total calcite content and the amount of clay in soil. In any database, quartz is a minor component of the clay fraction ranging from 0 to $15 \%$ with an average content of about $5 \%$. In both databases, hematite represents a minor fraction of the clay fraction, lower than $4.4 \%$. Hematite abundance is lower in our work compared to Nickovic et al. (2012) but as we have added goethite, the comparison can be made on the total iron oxide minerals. When we take the total iron oxide fraction, the cumulative abundance of hematite and goethite from our database amounts to a larger mass fraction (about $33 \%$ higher in average) than the hematite content from Nickovic et al. (2012).

\subsection{Implications for dust optical properties: single scattering albedo}

Most of the minerals in airborne dust, with the exception of iron oxide minerals, have similar optical properties in the shortwave part of the spectrum (from 0.2 to $4.0 \mu \mathrm{m}$ ). Here we use the refractive index of illite for everything except hematite and goethite. Hematite and goethite are more absorbing than the other minerals (Balkanski et al., 2007), 

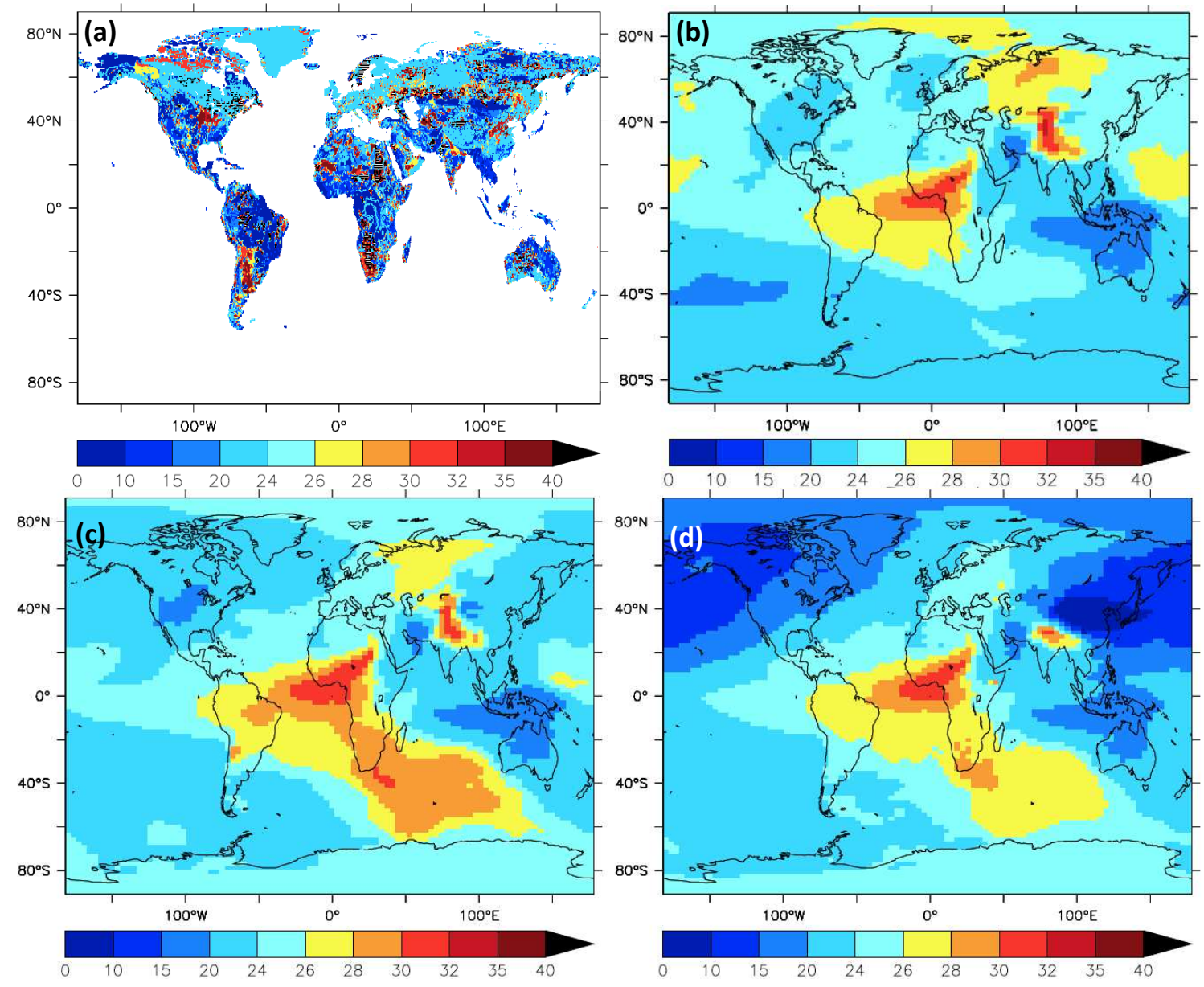

Fig. 11. Comparison of illite (mass \%) (a) in soil; (b) airbone, CASE 0; (c) airborne CASE 1; (d) airborne CASE 2.

hematite being even more absorbing than goethite. The same relative volume of hematite compared to goethite will absorb substantially more radiation in the shortwave spectrum and its density is $25 \%$ greater than goethite. The absorption of dust, and hence its single scattering albedo, depends not only on the total amount of optically active iron oxide minerals that are present but also on the relative proportion of hematite and goethite.

We used a core-shell optical model from Toon and Ackerman (1981) to calculate the albedo of dust over the whole range of relative abundances of illite, goethite and hematite shown in the database. The refractive index of this shell was determined using a dielectric model as described in Balkanski et al. (2007). These different core-shell assemblages are fully determined by two variables: the percentage of the total volume occupied by the shell made of iron oxide minerals (i.e., volume goethite + volume hematite (\%)) and the ratio, $R$, of the volume of hematite to the total volume of iron oxide minerals:

$R=$ Vol. Hematite $/($ Vol. Hematite + Vol. Goethite $)$.
Illite, goethite and hematite were transported as inert tracers in the general circulation model with an aerosol scheme (LMDZ-INCA). For each mineral, 5 years of simulations were analyzed to determine the volume fraction of illite, goethite and hematite relative to the volume of total dust. In these simulations, the yearly average volume fraction of iron oxide minerals relative to the total dust volume remains between 1.5 and $5 \%$ over most regions except over India where the values can fall below $1.5 \%$ (Fig. 14a). The plot of the $R$ ratio (Fig. 14b) shows that goethite is more abundant than hematite over both hemispheres $(R<0.5)$ except for a region centered over central Europe.

\subsection{Single scattering albedo of dust computed from iron oxide minerals}

We created a table with 286 values of the total iron oxide minerals mass and the $\mathrm{R}$ ratio to determine the single scattering albedo of the airborne dust. The values obtained for single scattering albedo, $\omega_{0}$, represent a yearly averaged situation (Fig. 15). Values for $\omega_{0}$ range from 0.935 to 0.975 . The 

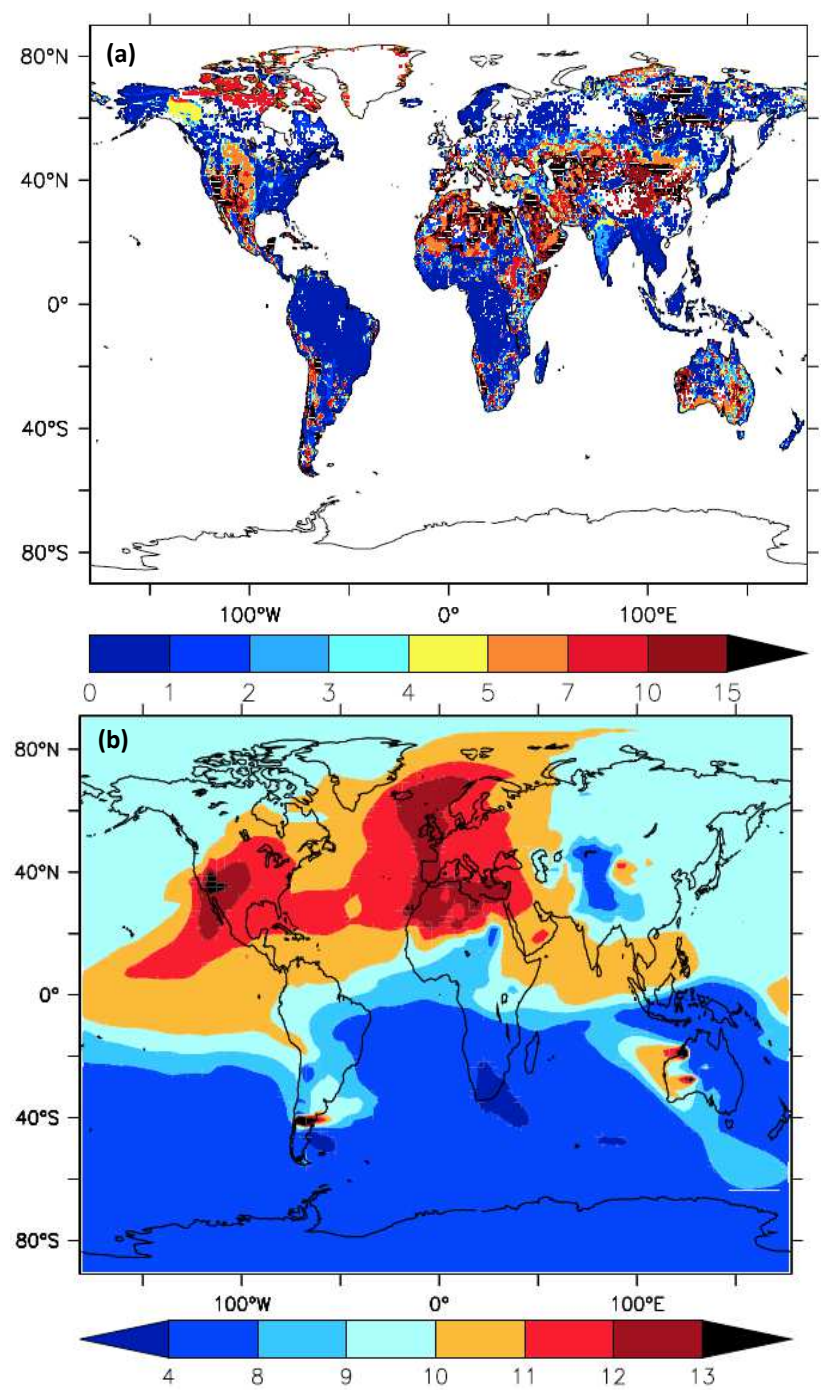

Fig. 12. Comparison of (a) soil and (b) airbone dust calcite content (mass \%).

gradients shown here cannot be obtained from any method based upon optical measurements.

\section{Conclusions}

There is a clear need for detailed information on mineralogy to improve assessments of the environmental and climatic impacts of dust. Although the size fractionation that occurs during emission leads to an aerosol composition that is different from the parent soil (Gomes, 1990; Grini et al., 2002; Kok, 2011), there is still much work required to quantify these differences. Given the lack of data on the mineralogical composition of airborne dust, an indirect approach using the size-resolved mineralogical composition of parent soils is still the best way of specifying dust mineralogy globally. Claquin et al. (1999) were the first to produce mineralogical (a)

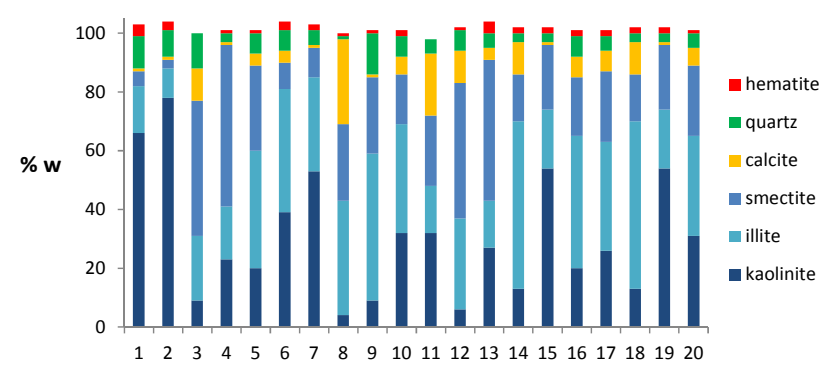

(b)

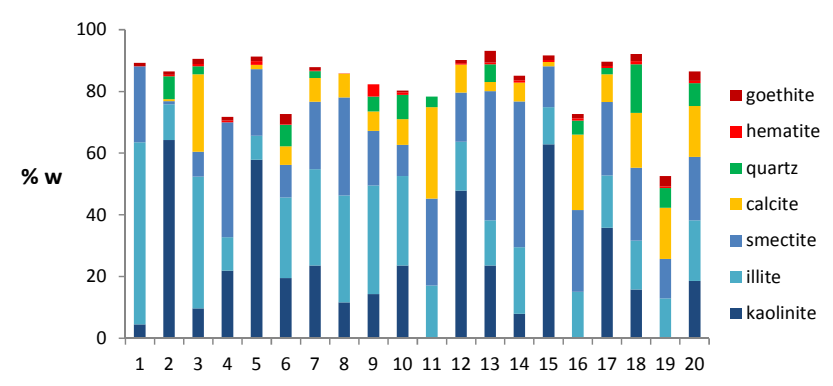

Fig. 13. Mean mineralogical composition of 20 FAO soils types: (a) Claquin et al. (1999) and Nickovic et al. (2012) and (b) this work.

maps of arid and semi-arid soils for this purpose, providing information on eight minerals (quartz, feldspars, calcite, gypsum, illite, kaolinite, smectite and hematite) in both the clay- and silt-sized soil fractions. More recently, Nickovic et al. (2012) revised these maps to include three new soil units and soil phosphorus contents. The present work is a major improvement on these earlier compilations, because it is not confined to arid and semi-arid soil units and provides information on a wider range of minerals.

Despite having the benefit of a more extensive literature, data is still lacking for a number of soil units and it was therefore necessary to make a number of assumptions to extrapolate mineralogical information to cover all soil subtypes. There is comparatively little information on the calcite and iron oxide mineral (hematite and goethite) contents of both the clay- and silt-sized fractions because they are almost always measured on the bulk soil. The same is true for gypsum. There is less information available about the mineralogy of silt compared to the clay fraction. This may be less important than the lack of information about the mineralogy of the clay-fraction because, although the silt fraction is important in dust total deposition, it is a less important component of the radiatively active fraction of dust that is transported long distances from the source regions. The data coverage for Australia, South America and Asia is not satisfactory. Information may be available for Asia, although we were unable to access this literature. Information on the mineralogical composition of ferralic Arenosols, luvic Yermosols, sodic 

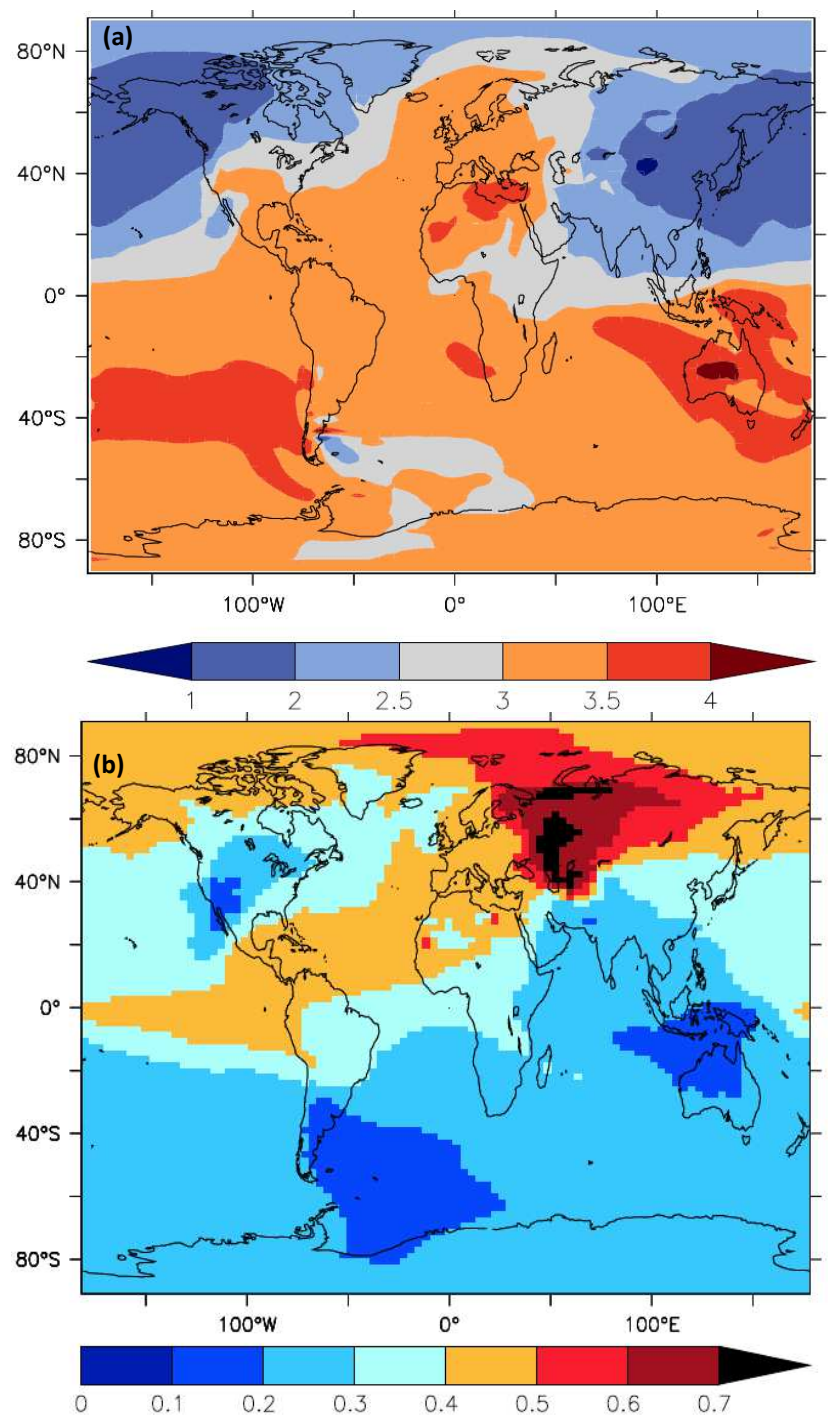

Fig. 14. (a) Mass in percent of hematite plus goethite and (b) elative mass ratio of hematite to hematite plus goethite.

Planosols and luvic Calcisols would considerably improve the database for Australia and South America. We have produced a dynamic database, designed to evolve through inclusion of new data. Data on the FAO soil units for which we were unable to obtain mineralogical information (see Table B1 in the Supplement), would greatly enhance the utility of the database. More information of the particle-size distribution of calcite, gypsum and iron oxide minerals would improve the level of confidence in the mineralogical maps.

The current database and associated mineralogical maps provides a tool for specifying dust mineralogy in dust-cycle simulations. It can be used to deduce the mineralogy of both modern dust sources and dust sources created by changed conditions. This opens the way to examine the impact of changing dust sources in response to past or future climate and land-use scenarios.

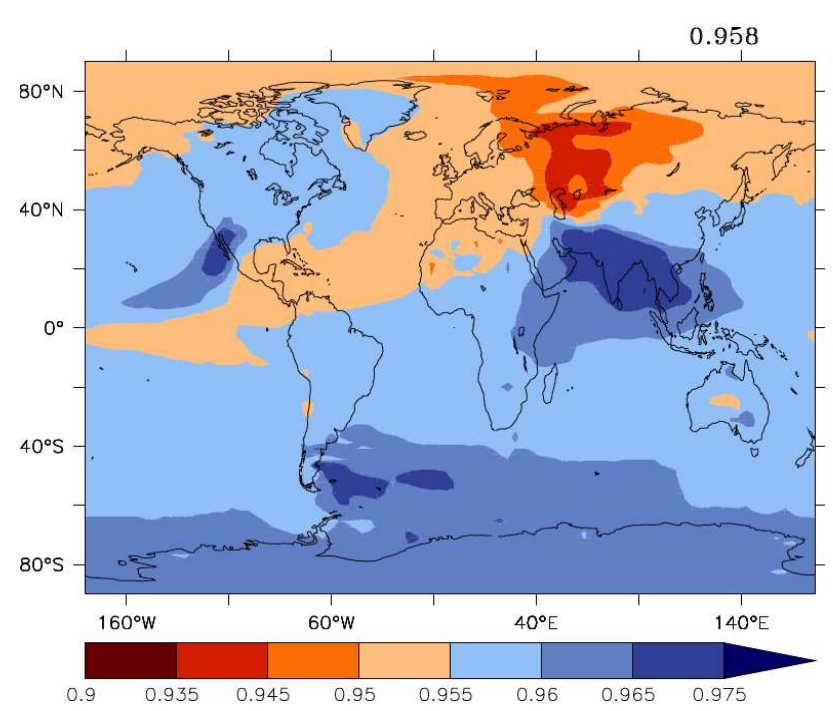

Fig. 15. Single scattering albedo of airborne dust.

\section{Supplementary material related to this article is

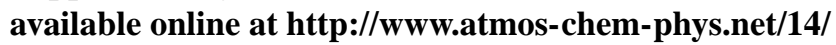 3801/2014/acp-14-3801-2014-supplement.pdf.}

Acknowledgements. The compilation of the mineralogical data was initially funded by the UK program QUEST (Quantifying Uncertainties in the Earth System), as part of the project Dynamics of the Earth System and the Ice-core Record (DESIRE).

Edited by: B. Vogel

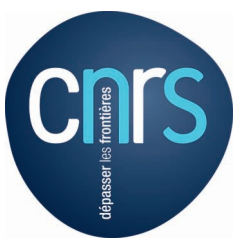

The publication of this article is financed by CNRS-INSU.

\section{References}

Abtahi, A.: Soil genesis as affected by topography and time in highly calcareous parent materials under semiarid conditions in Iran, Soil Sci. Soc. Am. J., 44, 329-336, doi:10.2136/sssaj1980.03615995004400020025x, 1980.

Andronova, V.: A study of the crystalline structure of vermiculite from the Tebinbulak deposit, Refract. Indust. Ceram., 48, 91-95, doi:10.1007/s11148-007-0035-3, 2007.

Atkinson, J. D., Murray, B. J., Woodhouse, M. T., Whale, T. F., Baustian, K. J., Carslaw, K. S., Dobbie, S., O'Sullivan, D., and Malkin, T. L.: The importance of feldspar for ice nucleation by mineral dust in mixed-phase clouds, Nature, 498, 355-358, doi:10.1038/nature12278, 2013.

Balkanski, Y., Schulz, M., Claquin, T., and Guibert, S.: Reevaluation of Mineral aerosol radiative forcings suggests a better agreement with satellite and AERONET data, Atmos. Chem. Phys., 7, 81-95, doi:10.5194/acp-7-81-2007, 2007. 
Bayrak, Y.: Application of Langmuir isotherm to saturated fatty acid adsorption, Micropor. Mesopor. Mater., 87, 203-206, doi:10.1016/j.micromeso.2005.08.009, 2006.

Caquineau, S., Gaudichet, A., Gomes, L., and Legrand, M.: Mineralogy of Saharan dust transported over northwestern tropical Atlantic Ocean in relation to source regions, J. Geophys. Res., 107, doi:10.1029/2000JD000247, 2002.

Carroll, D. and Starkey, H. C.: Reactivity of clay minerals with acids and alkalies, Clays Clay Miner., 19, 321-333, 1971.

Cathelineau, M. and Nieva, D.: A chlorite solid solution geothermometer the Los Azufres (Mexico) geothermal system, Contrib. Mineral. Petrol., 91, 235-244, doi:10.1007/BF00413350, 1985.

Chatenet, B., Marticorena, B., Gomes, L., and Bergametti, G.: Assessing the microped size distributions of desert soils erodible by wind, Sedimentology, 43, 901-911, doi:10.1111/j.13653091.1996.tb01509.x, 1996.

Claquin, T., Schulz, M., and Balkanski, Y.: Modeling the mineralogy of atmospheric dust sources, J. Geophys. Res., 104, 2224322256, doi:10.1029/1999JD900416, 1999.

Cornell, R. M. and Schwertmann, U.: The iron oxides: structure, properties, reactions, occurrences and uses, 2nd Edn., WileyVCH Pub., Weinheim, Germany, 2003.

Creamean, J. M., Suski, K. J., Rosenfeld, D., Cazorla, A., DeMott, P. J., Sullivan, R. C., White, A. B., Ralph, F. M., Minnis, P., Comstock, A. M., Tomlinson, J. M., and Prather, K. A.: Dust and biological aerosols from the Sahara and Asia influence precipitation in the western U.S., Science, 339, 1572-1578, doi:10.1126/science.1227279, 2013.

Cwiertny, D. M., Baltrusaitis, J., Hunter, G. J., Laskin, A., Scherer, M. M., and Grassian, V. H.: Characterization and acid-mobilization study of iron-containing mineral dust source materials, J. Geophys. Res., 113, D05202, doi:10.1029/2007JD009332, 2008a.

Cwiertny, D. M., Young, M. A., and Grassian, V. H.: Chemistry and photochemistry of mineral dust aerosol, Annu. Rev. Phys. Chem., 59, 27-51, doi:10.1146/annurev.physchem.59.032607.093630, 2008b.

Deer, W., Howie, R., and Zussman, J.: Rock-forming minerals, in: Sheet Silicates: Clay Minerals, vol. 3, 2nd Edn., Longmans, London, 1962.

Delany, A., Parkin, D. W., Griffin, J. J., Goldberg, E. D., and Reimann, B. E. F.: Airborne dust collected at Barbados, Geochim. Cosmochim. Acta, 31, 885-909, doi:10.1016/S00167037(67)80037-1, 1967.

DeMott, P. J., Sassen, K., Poellot, M. R., Baumgardner, D., Rogers, D. C., Brooks, S. D., Prenni, A. J., and Kreidenweis, S. M.: African dust aerosols as atmospheric ice nuclei, Geophys. Res. Lett., 30, 1732, doi:10.1029/2003GL017410, 2003.

Duce, R., Unni, C. K., Ray, B. J., Prospero, J. M., and Merrill, J. T.: Long-range atmospheric transport of soil dust from Asia to the tropical North Pacific - Temporal variability, Science, 209, 1522-1524, 1980.

FAO: Guidelines for Soil Profile Description, 3d Edn. (revised), Food and Agriculture Organization of the United Nations, International Soil Reference Information Centre, Land and Water Development Division, FAO, Rome, 1990a.

FAO: Caractéristique minéralogiques des sols, in: Études et prospections pédologiques en vue de l'irrigation, no. 42, Bulletin pédologique de la FAO, Rome, 26-29, $1990 \mathrm{~b}$.
FAO/IIASA/ISRIC/ISSCAS/JRC (Ed.): Harmonized World Soil Database (version 1.1), FAO, Rome, Italy and IIASA, Laxenburg, Austria, 2009.

FAO-UNESCO (Ed.): The legend of the Soil Map of the World, UNESCO, Paris, 1974.

Feely, R. A., Doney, S. C., and Cooley, S. R.: Ocean acidification: present conditions and future changes in a high- $\mathrm{CO}_{2}$ world, Oceanography, 22, 36-47, doi:10.5670/oceanog.2009.106, 2009.

Fontes, M. P. F. and Carvalho, I. A.: Color attributes and mineralogical characteristics, evaluated by radiometry of highly weathered tropical soils, Soil Sci. Soc. Am. J., 69, 1162-1172, 2005.

Gangas, N. H., Simopoulos, A., Kostikas, A., Yassoglou, N. J., and Filippakis, S.: Mössbauer studies of small particles of iron oxides in soil, Clays Clay Miner., 21, 151-160, 1973.

Ganor, E. and Mamane, Y.: Transport of Saharan dust across the eastern Mediterranean, Atmos. Environ., 16, 581-587, doi:10.1016/0004-6981(82)90167-6, 1982.

Garcia-Rodriguez, A., del Rey-Bueno, F., del Rey-Perez-Caballero, F. J., Ureña-Amate, M. D., and Mata-Arjona, A.: Synthesis and characterization of montmorillonite-(Ce or $\mathrm{Zr}$ ) phosphate crosslinked compounds, Mater. Chem. Phys., 39, 269-277, doi:10.1016/0254-0584(94)01439-N, 1995.

Gold, C., Cavell, P., and Smith, D.: Clay minerals in mixturessample preparation, analysis and statistical interpretation, Clays Clay Miner., 31, 191-199, 1983.

Gomes, L.: Approche géochimique du soulèvement des aérosols à l'interface sol-atmosphère en zone désertique, $\mathrm{Ph} . \mathrm{D}$. thesis, Université Paris 7, Paris, 1990.

Greenland, D. J., Oades, J., and Sherwin, T.: Electron-microscope observation of iron oxides in some red soils, J. Soil Sci., 19, 123126, doi:10.1111/j.1365-2389.1968.tb01526.x, 1968.

Griffin, D. W., Kellogg, C. A., Garrison, V. H., and Shinn, E. A.: The global transport of dust. An intercontinental river of dust, microorganisms and toxic chemicals flows through the Earth's atmosphere, Am. Sci., 90, 228-235, 2002.

Griffin, J. J., Windom, H., and Goldberg, E. D.: The distribution of clay minerals in the world ocean, Deep-Sea Res., 15, 433-459, doi:10.1016/0011-7471(68)90051-X, 1968.

Grini, A., Zender, C. S., and Colarco, P. R.: Saltation sandblasting behavior during mineral dust aerosol production, Geophys. Res. Lett., 29, 1868, doi:10.1029/2002GL015248, 2002.

Hansell, R., Liou, K. N., Ou, S. C., Tsay, S. C., Ji, Q., and Reid, J. S.: Remote sensing of mineral dust aerosol using AERI during the UAE2: A modeling and sensitivity study, J. Geophys. Res, 113, D18202, doi:10.1029/2008JD010246, 2008.

Jickells, T. D., An, Z. S., Andersen, K. K., Baker, A. R., Bergametti, G., Brooks, N., Cao, J. J., Boyd, P. W., Duce, R. A, Hunter K. A., Kawahata, H., Kubilay, N., laRoche, J., Liss, P. S., Mahowald, N., Prospero, J. M., Ridgwell, A. J., Tegen, I., and Torres, R.: Global iron connections between desert dust, ocean biogeochemistry and climate, Science, 308, 67-71, doi:10.1126/science.1105959, 2005.

Journet, E., Desboeufs, K. V., Caquineau, S., and Colin, J.-L.: Mineralogy as a critical factor of dust iron solubility, Geophys. Res. Lett., 35, L07805, doi:10.1029/2007GL031589, 2008. 
Kandler, K., Schütz, L., Deutscher, C., Eber, M., Hofmann, H., Jäckel, S., Jaenicke, R., Knippertz, P., Lieke K., Massling, A., Petzold, A., Schladitz, A., Weinzierl, B., Wiedensohler, A., Zorn, S., and Weinbruch, S.: Size distribution, mass concentration, chemical and mineralogical composition and derived optical parameters of the boundary layer aerosol at Tinfou, Morocco, during SAMUM 2006, Tellus B, 61, 32-50, doi:10.1111/j.16000889.2008.00385.x, 2009.

Kelly, J. T., Chuang, C. C., and Wexler, A. S.: Influence of dust composition on cloud droplet formation, Atmos. Environ., 41, 2904-2916, doi:10.1016/j.atmosenv.2006.12.008, 2007.

Kok, J. F.: Does the size distribution of mineral dust aerosols depend on the wind speed at emission?, Atmos. Chem. Phys., 11, 1014910156, doi:10.5194/acp-11-10149-2011, 2011.

Kramm, U.: Chloritoid stability in manganese rich low-grade metamorphic rocks, Venn-Stavelot Massif, Ardennes, Contrib. Mineral. Petrol., 41, 179-196, 1973.

Krueger, B. J., Grassian, V. H., Cowin, J. P., and Laskin, A.: Heterogeneous chemistry of individual mineral dust particles from different dust source regions: the importance of particle mineralogy, Atmos. Environ., 38, 6253-6261, doi:10.1016/j.atmosenv.2004.07.010, 2004.

Lafon, S., Rajot, J. L., Alfaro, S., and Gaudichet, A.: Quantification of iron oxides in desert aerosol, Atmos. Environ., 36, 1211-1216, doi:10.1016/j.atmosenv.2003.11.006, 2004.

Levin, Z., Ganor, E., and Gladstein, V.: The effects of desert particles coated with sulfate on rain formation in the eastern Mediterranean, J. Appl. Meteorol., 35, 1511-1523, 1996.

Mahowald, N. and Luo, C.: A less dusty future?, Geophys. Res. Lett., 30, 1903, doi:10.1029/2003GL017880, 2003.

Mahowald, N., Kohfeld, K., Hansson, M., Balkanski, Y., Harrison, S. P., Prentice, J. C., Schultz, M., and Rodhe, H.: Dust sources and deposition during the last glacial maximum and current climate: A comparison of model results with paleodata from ice cores and marine sediments, J. Geophys. Res., 104, 1589515916, doi:10.1029/1999JD900084, 1999.

Martin, J. H., Gordon, R. M., and Fitzwater, S. E.: The case for iron, Limnol. Oceanogr., 36, 1793-1802, 1991.

Mitchell, J. K. and Soga, K.: Fundamentals of soil behavior, 3rd Edn., John Wiley \& Son, New York, 2005.

Munsell Color Company: Munsell Soil Color Charts, Division of Kollmorgen Corp., Baltimore, 1975.

Nickovic, S., Vukovic, A., Vujadinovic, M., Djurdjevic, V., and Pejanovic, G.: Technical Note: High-resolution mineralogical database of dust-productive soils for atmospheric dust modeling, Atmos. Chem. Phys., 12, 845-855, doi:10.5194/acp-12-8452012, 2012.

Okin, G. S., Mahowald, N., Chadwick, O. A., and Artaxo, P.: Impact of desert dust on the biogeochemistry of phosphorus in terrestrial ecosystems, Global Biogeochem. Cy., 18, GB2005, doi:10.1029/2003GB002145, 2004.

Osthaus, B.: Kinetic studies on montmorillonites and nontronite by the acid-dissolution technique, Clays Clay Miner., 4, 301-321, 1956.

Pedro, G.: La genèse des argiles pédologiques, Ses implications minéralogiques, physico-chimiques et hydriques, Sci. Geol. Bull., 37, 333-347, 1984.

Rahn, K. A.: Silicon and aluminum in atmospheric aerosols: crustair fractionation?, Atmos. Environ., 10, 597-601, 1976.
Ramesh, A., Hasegawa, H., Maki, T., and Ueda, K.: Adsorption of inorganic and organic arsenic from aqueous solutions by polymeric Al/Fe modified montmorillonite, Sep. Purif. Technol., 56, 90-100, doi:10.1016/j.seppur.2007.01.025, 2007.

Robert, M.: The experimental transformation of mica toward smectite; relative importance of total charge and tetrahedral substitution, Clays Clay Miner., 21, 167-174, 1973.

Rosenfeld, D., Rudich, Y., and Lahav, R.: Desert dust suppressing precipitation: A possible desertification feedback loop, P. Natl. Acad. Sci. USA, 98, 5975-5980, 2001.

Schroth, A., Crusius, J., Sholkovitz, E. R., and Bostick, B. C.: Iron solubility driven by speciation in dust sources to the ocean, Nat. Geosci., 2, 337-340, doi:10.1038/ngeo501, 2009.

Schulz, M., Balkanski, Y., Guelle, W., and Dulac, F.: Role of aerosol size distribution and source location in a three-dimensional simulation of a Saharan dust episode tested against satellitederived optical thickness, J. Geophys. Res., 103, 10579-10592, doi:10.1029/97JD02779, 1998.

Schwertmann, U. and Kampf, N.: Properties of goethite and hematite in kaolinitic soils of Southern and Central Brazil, Soil Sci., 139, 344-350, 1985.

Seabaugh, J. L., Dong, H., Kukkadapu, R. K., Eberl, D. D., Morton, J. P., and Kim, J.: Microbial reduction of Fe (III) in the Fithian and Muloorina illites: contrasting extents and rates of bioreduction, Clays Clay Miner., 54, 67-79, doi:10.1346/CCMN.2006.0540109, 2006.

Seo, D. C., Cho, J. S., Lee, H. J., and Heo, J. S.: Phosphorus retention capacity of filter media for estimating the longevity of constructed wetland, Water Res., 39, 2445-2457, doi:10.1016/j.watres.2005.04.032, 2005.

Sokolik, I. N. and Toon, O. B.: Direct radiative forcing by anthropogenic airborne mineral aerosols, Nature, 381, 681-683, doi:10.1038/381681a0, 1996.

Sokolik, I. N. and Toon, O. B.: Incorporation of mineralogical composition into models of the radiative properties of mineral aerosol from UV to IR wavelengths, J. Geophys. Res., 104, 9423-9444, doi:10.1029/1998JD200048, 1999.

Swap, R., Garstan, M., Greco, S., Talbot, R., and Kallberg, P.: Saharan dust in the Amazon Basin, Tellus B, 44, 133-149, doi:10.1034/j.1600-0889.1992.t01-1-00005.x, 1992.

Takemura, T., Egashira, M., Matsuzawa, K., Ichijo, H., O’ishi, R., and Abe-Ouchi, A.: A simulation of the global distribution and radiative forcing of soil dust aerosols at the Last Glacial Maximum, Atmos. Chem. Phys., 9, 3061-3073, doi:10.5194/acp-93061-2009, 2009

Taylor, R. W., Shen, S., Bleam, W. F., and Tu, S. I.: Chromate removal by dithionite-reduced clays: evidence from direct X-ray adsorption near edge spectroscopy (XANES) of chromate reduction at clay surfaces, Clays Clay Miner., 48, 648-654, 2000.

Tegen, I., Werner, M., Harrison, S. P., and Kohfeld, K. E.: Relative importance of climate and land use in determining present and future global soil dust emission, Geophys. Res. Lett., 31, L05105, doi:10.1029/2003GL019216, 2004.

Temuujin, J., Burmaa, G., Amgalan, J., Okada, K., Jadambaa, T., and MacKenzie, K. J. D.: Preparation of porous silica from mechanically activated kaolinite, J. Porous Mater., 8, 233-238, doi:10.1023/A:1012244924490, 2001. 
Toon, O. B. and Ackerman, T.: Algorithms for the calculation of scattering by stratified spheres, Appl. Optics, 20, 3657-3660, doi:10.1364/AO.20.003657, 1981.

Torrent, J., Schwertmann, U., Fechter, H., and Alferez, F.: Quantitative relationships between soil color and hematite content, Soil Sci, 136, 354-358, 1983.

Usher, C. R., Michel, A. E., and Grassian, V. H.: Reactions on mineral dust, Chem. Rev., 103, 4883-4940, doi:10.1021/cr020657y, 2003.

Werner, M., Tegen, I., Harrison, S. P., Kohfeld, K. E., Prentice, I. C., Balkanski, Y., Rodhe, H., and Roelandt, C.: Seasonal and interannual variability of the mineral dust cycle under present and glacial climate conditions, J. Geophys. Res.-Atmos., 107, 4744, doi:10.1029/2002JD002365, 2002.
Woodward, S., Roberts, D. L., and Betts, R. A.: A simulation of the effect of climate change-induced desertification on mineral dust aerosol, Geophys. Res. Lett., 32, L18810, doi:10.1029/2005GL023482, 2005.

Yilmaz, H.: Genesis of uranium deposits in Neogene sedimentary rocks overlying the Menderes metamorphic massif, Turkey, Chem. Geol., 31, 185-210, doi:10.1016/0009-2541(80)90086-8, 1981. 